Eur J Clin Chem Clin Biochem

1995; 33:65-71

(c) 1995 Walter de Gruyter \& Co.

Berlin · New York

\title{
Expression Pattern of Matrix Metalloproteinases in Human Liver
}

\author{
By Ralf Lichtinghagen ${ }^{1}$, Tanja Helmbrecht ${ }^{1}$, Burkhard Arndt ${ }^{1}$ and Klaus H. W. Böker
}

1 Institut für Klinische Chemie I im Zentrum Laboratoriumsmedizin der Medizinischen Hochschule Hannover, Hannover, Germany

2 Abteilung für Gastroenterologie und Hepatologie im Zentrum Innere Medizin der Medizinischen Hochschule Hannover, Hannover, Germany

(Received August 12/December 16, 1994)

Summary: Antibodies were raised against seven major matrix metalloproteinases: stromelysin-1 (MMP-3), stromelysin-2 (MMP-10), stromelysin-3 (MMP-11), interstitial collagenase (MMP-1), $M_{\mathrm{r}} 72000$ type IV collagenase (72 kDa type IV collagenase, MMP-2), $M_{\mathrm{r}} 92000$ type IV collagenase ( $92 \mathrm{kDa}$ type IV collagenase, MMP-9) and matrilysin (PUMP, MMP-7) as well as against prolyl 4-hydroxylase, to study the expression of these collagenolytic enzymes in normal liver in relation to the activity of collagen synthesis. Tissue samples of four normal human livers, three hepatocellular carcinomas and one cholangiocellular carcinoma were analysed. In normal liver we found expression of stromelysin-1, stromelysin-3, interstitial collagenase, $M_{\mathrm{r}} 72000$ and $M_{\mathrm{r}} 92000$ type IV collagenases and varying expression of prolyl 4-hydroxylase. Stromelysin-2 was inconsistently detectable; matrilysin was not found. In hepatocellular carcinoma the expression pattern of matrix metalloproteinases showed only minor changes compared with the normal tissue; stronger signals than in normal tissue were seen for stromelysin-1, and stromelysin-2 was also strongly positive. $M_{\mathrm{r}} 72000$ and $M_{\mathrm{r}} 92000$ type IV collagenases and interstitial collagenase were less strongly expressed; stromelysin-3 was unchanged. Expression of prolyl 4-hydroxylase was also increased compared with normal liver. Matrilysin was only seen in cholangiocellular carcinoma, which showed a completely different pattern of matrix metalloproteinase expression.

Our results show that metalloproteinases are expressed in human liver with much greater abundance than previously described. Their expression pattern is not changed fundamentally in hepatocellular carcinoma but is completely different from that of other tumour tissues such as cholangiocellular carcinoma.

\section{Introduction}

The normal liver matrix contains about 4-6 mg collagen per gram liver tissue. In fibrotic diseases the collagen content is significantly increased, reaching as much as $30 \%$ of the total liver weight (1). Extracellular matrix consists of different collagens, of which collagen type I is the most abundant, comprising up to $70 \%$ of the extracellular matrix in fibrotic liver.

While considerable progress has been made concerning the cellular source of matrix proteins (collagens, glycosaminoglycans and glycoproteins) and the regulation of their expression $(2,3)$, the amount and rate of collagen breakdown and matrix turnover in normal and diseased liver is still poorly understood.

Circumstantial evidence suggests that in normal liver collagen synthesis and turnover are balanced, keeping the collagen content fairly stable (4). In chronic diseases this balance might be tilted towards an increasing predominance of fibrogenesis, resulting in an accumulation of collagenous matrix and finally organ fibrosis and cirrhosis.

Collagen turnover is largely the effect of matrix metalloproteinases, a family of neutral proteinases requiring zinc ions for activity and digesting different collagens 
and gelatins (denatured collagen derivatives) $(5,6)$. Their activity is regulated both on the transcriptional level, by proenzyme activation and finally by inhibitors which are coexpressed and are present at the tissue sites of enzyme activity (7). Earlier reports suggest that hepatic perisinusoidal (Ito-) cells, besides producing different collagens are also capable of expressing matrix metalloproteinases $(8-10)$. High levels of collagenase activity have been found in alcoholic liver disease with active fibrogenesis and after carbon tetrachloride poisoning in the rat. It is not known however, which of the numerous collagenases were responsible for this effect $(11,12)$.

Other investigators found $M_{\mathrm{r}} 72000$ type IV collagenase (MMP-2) transcripts in normal and both interstitial collagenase (MMP-1) and $M_{\mathrm{r}} 72000$ type IV collagenase transcripts in fibrotic human liver (13). Very little is known about the expression of other matrix metalloproteinases or their inhibitors in the human liver in vivo (14).

In the study presented here, we investigated the expression of seven major matrix metalloproteinases and of prolyl 4-hydroxylase, the rate limiting enzyme of posttranslational modification of collagen, in normal human liver and in hepatocellular as well as cholangiocellular tumour tissue. The aim of the study was to establish laboratory methods for further studies of metalloproteinase expression and to determine which metalloproteinase repertoire is found in normal liver.

\section{Materials and Methods}

Production of specific antisera against different matrix metalloproteinases and prolyl 4-hydroxylase

Fragments of cDNA, coding for parts of the haemopexin-like domain (15) of stromelysin-1 ${ }^{1}$ ), stromelysin-2 ${ }^{1}$ ), stromelysin-3 $\left.{ }^{1}\right), M_{\mathrm{r}}$ 72000 type IV collagenase ${ }^{\prime}$ ), $M_{\mathrm{r}} 92000$ type IV collagenase' ${ }^{\prime}$ ), interstitial collagenase ${ }^{1}$ ), for part of the propeptide- and catalytic domain of matrilysin ${ }^{1}$ ) and the carboxy-terminus of the $\alpha$-subunit of prolyl 4-hydroxylase') were cloned into bacterial expression vec-

1) Enzymes

Stromelysin-1 (MMP-3):

Stromelysin-2 (MMP-10):

Stromelysin-3 (MMP-11):

Matrilysin (MMP-7):

$M_{\mathrm{r}} 72000$ type IV collagenase (MMP-2):

$M_{\mathrm{r}} 92000$ type IV collagenase (MMP-9):

Interstitial collagenase (MMP-1):

Prolyl 4-hydroxylase:

EcoRI: Restriction endonuclease from Escherichia coli

HindIII: Restriction endonuclease from Haemophilus influenzae Rd

Bam HI: Restriction endonuclease from Bacillus amyloliquefaciens $\mathrm{H}$

Xbal: $\quad$ Restriction endonuclease from Xanthomonas campestris pv. badrii tors pGEX-2T (16), pET-2la(t) (17) and pUR-288 (18) as follows.

cDNA sequences coding for weakly conserved domains of the proteins were amplified by polymerase chain reaction (PCR) as described by Saiki et al. (19) using the following oligonucleotide primers:

Stromelysin-1 (MMP-3)

STR1: S'TAT GGA TCC CCC CCT GAC TCC CCT GAG ${ }^{3 \prime}$ 5'ATG GAA TTC AGG TTC AAG CTT CCT GAG G

STROM: ${ }^{5}$ CTG GGA TCC GAC ACT CTG GAG GTG ATG $C^{3 \prime}$ ${ }^{5} \mathrm{CGA}$ GAA TTC AAT TGG TCC CTG TTG TAT CC $^{3}$

Stromelysin-2 (MMP-10)

STR2: $\quad$ 'TAC GGA TCC CCC CCT GCC TCT ACT GAG G ${ }^{3 \prime}$ ${ }^{51}$ ATG GAA TTC AGG TTC AGG GTT CCA GTG G ${ }^{3}$

Stromelysin-3 (MMP-11)

STR3: S'ACA GGA TCC AAG GCC CTG ATG TCC GCC TTC $^{3}$

S'CTC GAA TTC AGC GTC CAC AGG GCT GGG C

Matrilysin (MMP-7)

PU: $\quad$ 5'CCT GGA TCC CTG GCC CTG CCG CTG CCT ${ }^{31}$

5'AAT GAA TTC ATG TTC TGC CTG AAG TTT C ${ }^{31}$

$M_{\mathrm{r}} 72000$ type IV collagenase (MMP-2)

$72 \mathrm{KD}:{ }^{5}$ CGT GGA TCC TAT GGG GCC TCT CCT G ${ }^{3 \prime}$

5'GCG GAA TTC ACT CGC TGG ACA TCA GGG ${ }^{3 !}$

$M_{\mathrm{r}} 92000$ type IV collagenase (MMP-9)

$92 \mathrm{KD}:{ }^{51} \mathrm{CGT}$ GGA TCC GAC GAC GTG AAT GGC $\mathrm{A}^{31^{-3-}}$

5'TGC GAA TTC ACG TCG AAC CTC CAG AGG'

Interstitial collagenase (MMP-1)

IC: $\quad$ 'GAT GGA TCC CAA GCC ATA TAT GGA CGT $\mathrm{TCC}^{31}$

5'TTG GAA TTC CGG ACT TCA TCT CTG TCG G'"

Prolyl 4-hydroxylase ( $\alpha$-subunit)

PH: $\quad$ s'AAG GGA TCC TGG CTC TCT GGC TAT GA ${ }^{3 \prime}$

${ }^{5}$ ATC GAA TTC TCC ACT GGC AAA CAG A $^{3 !}$

The denaturing temperature was $94^{\circ} \mathrm{C}$, annealing temperatures were $54-59^{\circ} \mathrm{C}$. Thirty-five cycles at $72^{\circ} \mathrm{C}$ were run using first strand cDNA matrices $(0.2 \mu \mathrm{g})$ derived from human breast carcinoma (for stromelysin- $1,-2,-3$ ) or a liver metastasis of a colon carcinoma (for matrilysin, $M_{\mathrm{r}} 72000$ and $M_{\mathrm{r}} 92000$ type IV collagenases, interstitial collagenase and prolyl 4-hydroxylase), respectively. For cloning purposes, BamHI recognition sites were included in the sense and $E c o$ R recognition sites in the antisense primers. After amplification, DNA fragments

STR1: nucleotides 830-1024, amino acids 263-327, (20) STR2: nucleotides 806-1000, amino acids 262-326, (21) STR3: nucleotides 688-1053, amino acids 227-347, (22) PU: nucleotides 64- 858, amino acids 16-267, (23) IC: nucleotides 826-1097, amino acids 257-340, (24) 72KD: nucleotides 1279-1665, amino acids $315-437,(25)$ $92 \mathrm{KD}: \quad$ nucleotides $1319-1938$, amino acids $434-637,(26)$ PH: $\quad$ nucleotides 1262-1603, amino acids 368-475, (27)

were digested with restriction enzymes $\left.B a m \mathrm{HI}^{1}\right)$ and $\left.E c o \mathrm{RI}^{1}\right)$ and then ligated with BamHI/EcoRI cut pGEX-2T-DNA yielding STR1-, STR2-, STR3-, PU-, IC-, 72KD-, 92KD- and PH-pGEX expression clones, respectively. Sequences were similary cloned into the expression vector pET-2la $(+)$ using DNA fragments amplified by PCR with primer pairs as above except that EcoRI recognition sites were substituted by HindIII ${ }^{1}$ ) sites. When using the pUR-288 expression vector, EcoRI sites were substituted by $X^{2}{ }^{1} I^{1}$ ) sites. Clones were checked by sequencing (28).

Expression of the fusion proteins was induced with $0.5 \mathrm{mmol} / \mathrm{l}$ isopropyl $\beta$ - $D$-thiogalacto-pyranoside för pGEX (yielding a fusion protein with $M_{\mathrm{r}} 27500$ glutathione S-transferase at the amino-ter- 
minus), pET-21a(+) constructs (giving a fusion protein with a 18 amino acids peptide, including a histidine-tag, at the carboxy-terminus) and pUR-288 (amino-terminal fusion with $M_{\mathrm{r}} 116000$ of $\beta$-galactosidase). Cells were lysed by sonication three hours after induction and centrifuged at $10000 \mathrm{~g}$. The pellets were resuspended in SDS sample buffer and subjected to preparative SDS polyacrylamide gel electrophoresis; bands containing the induced fusion proteins were excised and electroeluted using a Biotrap apparatus (Schleicher \& Schüll, Germany). Purity of the recovered proteins was assayed by analytical SDS polyacrylamide gel electrophoresis. Protein concentrations were determined colorimetrically with coomassie brilliant blue staining (29). The pGEX fusion proteins were used to immunize 4- to 5-month old Chinchilla rabbits following standard protocols (30). Specificities of the antisera were determined by enzyme-linked immunosorbent-assay (ELISA) (30) using either pGEX fusion proteins after affinity chromatography on glutathione-sepharose columns (Pharmacia) and thrombin-cleavage (STR1, STR2) (16), pET constructs (STR3, PU, IC and $\mathrm{PH}$ ) or pUR fusion proteins ( $72 \mathrm{KD}$ and $92 \mathrm{KD}$ ) as antigens to avoid cross reactivities from the glutathione S-transferase part of the fusion protein.

Sera were stored in aliquots at $-20^{\circ} \mathrm{C}$ until used. An additional construct (STROM-pGEX) encompassing an amino-terminal portion of stromelysin-1 (STROM: nucleotides 227-646, amino acids 72-210) was prepared like STR1-pGEX for characterizing specific antibodies against PUMP.

Enzyme-linked immunosorbent-assay (ELISA) (30)

Microtitre plates were coated overnight with $100 \mu \mathrm{l}$ of the antigen $(1 \mathrm{mg} / 1)$ diluted in coating buffer (106 g/l Na $\mathrm{CO}_{3}, 336 \mathrm{~g} / \mathrm{l}$ $\mathrm{NaHCO}_{3}$ ) and then blocked for $30 \mathrm{~min}$ in an additional $150 \mu \mathrm{l}$ blocking buffer $\left(50 \mathrm{mmol} / 1 \mathrm{NaH}_{2} \mathrm{PO}_{4}, 150 \mathrm{mmol} / \mathrm{l} \mathrm{NaCl}, 0.5 \mathrm{~g} / \mathrm{l}\right.$ Tween $20,0.2 \mathrm{~g} / 1 \mathrm{NaN}_{3}, 1 \mathrm{~g} / \mathrm{l}$ haemoglobin; $\mathrm{pH}$ 7.2). The plates were washed three times with $200 \mu \mathrm{l}$ washing buffer (blocking buffer without haemoglobin). Hundred $\mu$ l of crude antisera diluted in blocking buffer were incubated for two hours (dilutions are indicated in the legend to fig. 1) then washed three times with $200 \mu \mathrm{l}$ phosphate-buffered saline before peroxidase conjugated sheep antirabbit IgG antibody ( $1: 500)$ (Boehringer Mannheim) was added. After a 30 min incubation it was washed three times with phosphate-buffered saline. The antibody complex was visualized $10 \mathrm{~min}$ after addition of the chromogen di-ammonium 2,2'-azino-bis(3ethylbenzothiazoline-6-sulphonate) (ABTS) (Boehringer Mannheim) giving raise to a green colour whose intensity was measured at $405 \mathrm{~nm}$.

\section{Tissue preparation}

Normal liver tissue was obtained from four explanted livers which were meant for liver transplantation but could not be utilized for reasons unrelated to this study. Tumour tissue was excised from resected neoplasms immediately in the operation theatre and placed in cold Ringer lactate solution (Baxter) on crushed ice. Three hepatocellular carcinomás and one cholangiocellular carcinoma were analysed. Pieces of approximately $100 \mathrm{mg}$ were homogenized in $300 \mu \mathrm{l}$ SDS sample buffer $(125 \mathrm{mmol} / 1 \mathrm{Tris} / \mathrm{HCl}, \mathrm{pH} 6.8,30 \mathrm{~g} / 1$ sodium dodecylsulphate, $50 \mathrm{~g} / 1$ 2-mercaptoethanol, $150 \mathrm{~g} / 1$ glycerol) using an ultra-turrax (Kinematica). The samples were boiled for $10 \mathrm{~min}$, centrifuged at $10000 \mathrm{~g}$ and the supernatant was stored at $-20^{\circ} \mathrm{C}$

\section{Western blot analysis}

The tissue extracts $(1-4 \mu l$, see tissue preparation) were subjected to analytical SDS polyacrylamide gel electrophoresis (gel size: 6.0 $\times 8.5 \mathrm{~cm}$ ) and then transferred to nitrocellulose strips (BA85, Schleicher \& Schuell) in a Sartoblot2 transfer appartus (Sartorius). A set of prestained protein standards was simultaneously run on SDS polyacrylamide gel electrophoresis and transferred to excised strip. The blotted membrane was blocked over night with $1 \%$ blocking reagent (Boehringer Mannheim) in Tris-buffered saline ( $50 \mathrm{mmol} / \mathrm{l}$ Tris base, $150 \mathrm{mmol} / \mathrm{l} \mathrm{NaCl}, \mathrm{pH} \mathrm{7.5).} \mathrm{Subsequently,}$ membrane strips were incubated for two hours at room temperature with the primary antiserum diluted in $5 \mathrm{~g} / \mathrm{l}$ blocking reagent in Trisbuffered saline (dilutions are indicated in the legend to fig. 2). Membrane strips were washed two times in Tris-buffered saline with $1 \mathrm{~g} / 1$ Tween 20 , two times in $5 \mathrm{~g} / 1$ blocking reagent in Trisbuffered saline, and incubated for a further hour with peroxidaseconjugated sheep anti-rabbit IgG (Boehringer Mannheim; $1: 1000$ in $5 \mathrm{~g} / \mathrm{l}$ blocking reagent in Tris-buffered saline). After four washing steps in Tris-buffered saline (with $1 \mathrm{~g} / \mathrm{l}$ Tween 20) immunoreactive bands were visualized using a luminol-based detection system (Boehringer Mannheim) and a 1 min exposure to X-OMAT AR-film (Kodak). For competition analysis, diluted primary antisera were preincubated with fusion proteins $(10 \mathrm{mg} / \mathrm{l})$ for twelve hours, prior to incubation with the membrane strip.

\section{Cell isolation}

Ten day old cultures of hepatic cell preparations were analysed. Cells were isolated by the two step collagenase method according to Seglen (31). After isolation the entire cell-suspension, containing hepatocytes and all non-parenchymal cell fractions was cultured on collagen-coated plastic dishes in medium 199 earle (Seromed) supplemented with insulin, dexamethasone, penicillin/streptomycin and $100 \mathrm{~g} / \mathrm{l}$ fetal calf serum. Cells were seeded at a density of approximately $4 \times 10^{6}$ per $25 \mathrm{~cm}^{2}$ dish. Medium was changed every 24 hours. Cells were harvested on day ten by removing them from the culture dish with a rubber policeman. They were washed three times with phosphate-buffered saline, centrifuged at $10000 \mathrm{~g}$, homogenized and analysed as described for tissue samples.

\section{Results}

\section{Antibody engineering}

Using published cDNA sequences of seven major matrix metalloproteinases, we selected primers and amplified cDNA sequences of these proteins from human tumour tissues by the polymerase chain reaction (see Materials and Methods). cDNA sequences were derived from parts of the haemopexin-like domain of the matrix metalloproteinase gene family. In the case of matrilysin, where this region is completely absent, we selected the propeptide and catalytic domain (15). The cDNA sequences chosen show as little sequence homology to other members of the matrix metalloproteinase family on the protein level as possible. The amplified cDNA fragments were shown to be of the expected molecular size and were sequenced and found to be identical to the published cDNA sequences (20-27). They were cloned into bacterial expression vectors in E. coli (see Materials and Methods). Since the sequences chosen did not contain glycosylation sites, the synthesized proteins could successfully be used as antigenic substitutes in rabbits, inducing antibodies which should specifically recognize a single member of the matrix metalloproteinase family. 


\section{Specificity of the raised antisera}

Figure 1 shows the results of ELISA-testing of crude rabbit-antisera against their own and related recombinant antigens. Comparisons between STR1-, STR2-, STR3-, IC-, $72 \mathrm{KD}$ - and $92 \mathrm{KD}$-antigens were performed with each antisera. For testing anti-PU (anti-matrilysin) we used a recombinant stromelysin-1 (STROM) which corresponds to the homologous region of the matrilysin-antigen (see Materials and Methods). All the antisera recognized their respective recombinant antigens with sufficient specificity. Anti-STR1 (anti-stromelysin1) cross reacted with both the stromelysin-1 and the stromelysin-2 antigen, while anti-STR2 (anti-stromelysin-2) only showed a weak cross-reactivity with stromelysin-1.

Immunoblotting (western blots, see fig. 2) revealed that the antisera also reacted with the intact human matrix metalloproteinase proteins. The shown reference blots

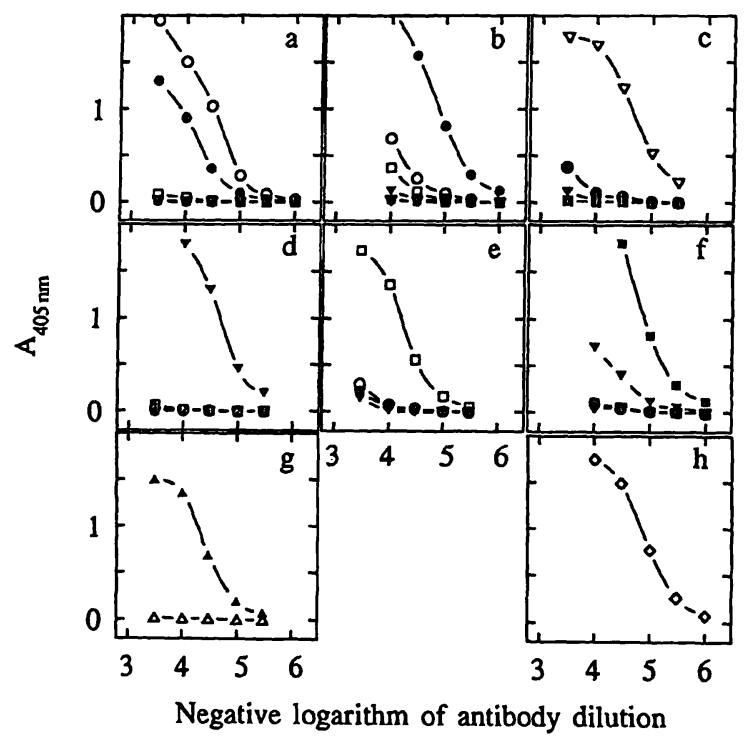

Fig. 1 Determination of the specificity of each antiserum against recombinant protein fragments.

ELISA analysis of the cross reactivity of crude antisera against homologous MMP-antigens:

a) anti-STR1 (stromelysin-1),

b) anti-STR2 (stromelysin-2),

c) anti-STR3 (stromelysin-3),

d) anti-72 $\mathrm{KD}\left(M_{\mathrm{r}} 72000\right.$ type IV collagenase),

e) anti-92 $\mathrm{KD}\left(M_{\mathrm{r}} 92000\right.$ type IV collagenase),

f) anti-IC (interstitial collagenase),

g) anti-PU (matrilysin),

h) anti-PH (prolyl 4-hydroxylase, $\alpha$-subunit).

Antigens are represented as:

$\begin{array}{ll}\text { STR1 } & (-0-), \\ \text { STR2 } & (-0-), \\ \text { STR3 } & (-\nabla-), \\ 72 \text { KD } & (-\nabla-), \\ 92 \text { KD } & (-\square-), \\ \text { IC } & (-\square-), \\ \text { STROM } & (-\Delta-), \\ \text { PU } & (-\Delta-) \text { and } \\ \text { PH } & (-\diamond-) \text { (see Materials and Methods). }\end{array}$

Absorbances were measured at $405 \mathrm{~nm}$ and plotted against dilution of antisera listed as negative logarithms. demonstrate that dominant bands of the appropriate molecular size were detected by the antisera in preparations derived from cultures of human liver cells, tumour tissue and serum.

Each antiserum detected a band of, the molecular size reported in the literature for the proenzyme form of the individual matrix metalloproteinase. Other bands also visible were not competitively inhibitable (data not shown), but in no case showed comparable intensities to the dominant ones.

Anti-STR1 (anti-stromelysin-1) and anti-STR3 (antistromelysin-3) recognized bands comigrating with the $M_{\mathrm{r}} 67000$ marker band, anti-IC (anti-interstitial collagenase) and anti-STR2 (anti-stromelysin-2) reacted with a band above the $M_{\mathrm{r}} 50000$ marker band, anti-72 $\mathrm{KD}$ (anti- $M_{\mathrm{r}} 72000$ type IV collagenase) recognized a band of approximately $M_{\mathrm{r}} 72000$, and anti-92 $\mathrm{KD}$ (anti- $M_{\mathrm{r}}$ 92000 type IV collagenase) recognized a band above the $M_{\mathrm{r}} 89000$ marker band. Anti-PU (anti-matrilysin) reacted with a band comigrating with the smallest marker band of $M_{\mathrm{r}} 34000$; the band detected by anti-PH (anti-prolyl 4-hydroxylase) was just smaller than the $M_{\mathrm{r}}$ 67000 marker band.

\section{Expression of matrix metalloproteinases}

We used our antisera to detect matrix metalloproteinases in normal human liver and in hepatic tumours. Figure 3 shows the results of western blots done with homogenized liver or tumour tissue.

In normal human liver we found stromelysin-1 and -3 , interstitial collagenase, both type IV collagenases $\left(M_{\mathrm{r}}\right.$ 72000 and $M_{\mathrm{r}} 92000$ ) and differing quantities of prolyl 4-hydroxylase. Stromelysin-2 was only inconsistently detectable and showed very weak bands, and matrilysin was not detectable. Stromelysin-1 and $M_{\mathrm{r}} 72000$ type IV collagenase seemed to be the most abundant of the matrix metalloproteinases in normal liver.

In the three hepatocellular carcinomas, the matrix metalloproteinase content seemed to be about the same as in normal tissue, although the expression level did seem to vary: most interestingly, stromelysin-2, hardly detectable in normal liver, was strongly positive in two of three hepatocellular carcinomas tested. Interstitial collagenase and both $M_{\mathrm{r}} 72000$ and 92000 type IV collagenases were less strongly detectable in the tumours. Thus stromelysins seemed to be upregulated in the tumours, while all the collagenases tested were not.

Neither in normal liver nor in hepatocellular carcinoma could wè detect any matrilysin protein.

Prolyl 4-hydroxylase was also more strongly positive in hepatocellular carcinoma than in hormal liver. 


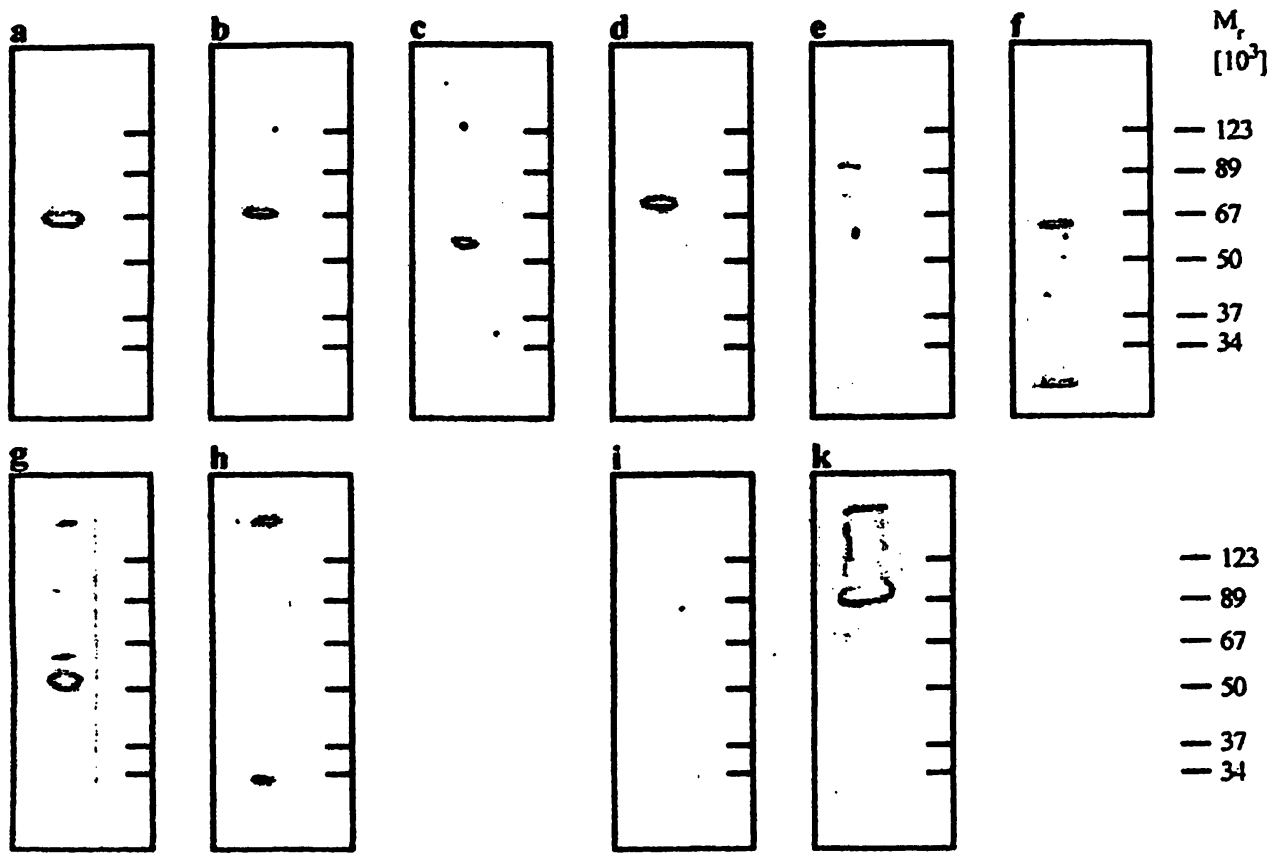

Fig. 2 Immunoblot determination of the specific recognition of human matrix metalloproteinases and prolyl 4-hydroxylase by newly raised antisera.

Crude cell-preparations of liver cells were separated by $9 \%$ SDS polyacrylamide gel electrophoresis, immunoblotted using polyclonal

anti-STR1 (anti-stromelysin-1, $1: 2000$, a);

anti-STR3 (anti-stromelysin-3, 1:1000, b);

anti-IC (anti-interstitial collagenase, $1: 500$, c);

anti-72 KD (anti- $M_{\mathrm{r}} 72000$ type IV collagenase, $1: 2000$, d);

anti-92 KD (anti- $M_{\mathrm{r}} 92000$ type IV collagenase, $1: 500$, e);

anti-PH (anti-prolyl 4-hydroxylase, $\alpha$-subunit, $1: 1000, f$;

anti-STR2 (anti-stromelysin-2, 1:1000, g);

anti-PU (anti-matrilysin, $1: 500, \mathrm{~h}$ );

The one cholangiocellular carcinoma tested showed an altogether different pattern of matrix metalloproteinases. Interstitial collagenase and $M_{\mathrm{r}} 92000$ type IV collagenase were not detectable, while stromelysin-2 was less intense than in the hepatocellular carcinomas. Stromelysin- 1 and stromelysin- 3 showed bands of smaller size in the cholangiocellular carcinoma than in all other tissues tested. Matrilysin was only detectable in the cholangiocellular carcinoma. Prolyl 4-hydroxylase was not found.

\section{Discussion}

Many authors believe that hepatic fibrosis and cirrhosis occur in situations of a disturbed equilibrium between collagen synthesis and degradation within the liver (4, 5). Following this hypothesis one would expect to find both collagen synthesis as well as collagen degradation in the normal liver. However, although this hypothesis is not a new one (32) little is known about the expression of collagenolytic enzymes in normal or diseased human liver. antisera and visualized using a luminol-based detection system. For controls antisera were blocked by preincubation with the corresponding antigens always yielding blank strips, as shown here in the case of anti-72 KD (i). Strong signals were detected with anti$92 \mathrm{KD}$ using human serum from a patient with posthepatic cirrhosis as shown in (k). The antibodies always recognized bands with apparent molecular masses, which correlated well with published data. Molecular mass markers were a set of prestained proteins (prestained SDS-PAGE standard solution, (Sigma) with molecular masses of native proteins $\left[M_{\mathrm{r}}, 10^{3}\right]$ of $27,36,45,58,84$ and 116 ) with apparent molecular masses $\left[M_{r}, 10^{3}\right]$ of $34,37,50,67,89$ and 123.

Arthur and coworkers described synthesis and expression of type IV collagenase by rat and human lipocytes $(9,10)$. This expression increased during the process of lipocyte activation, which is thought to take place also during the development of hepatic fibrosis (33). Milani et al. demonstrated mRNA transcription for $M_{\mathrm{r}} 72000$ type IV collagenase in both normal and diseased human liver by in situ hybridisation (13). They could not detect any mRNA for interstitial collagenase, however, and did not look for any other metalloproteinases. The main source of the mRNA detected was mesenchymal cells, thought to be perisinusoidal lipocytes.

In regenerating rat liver, Herbst et al. found increasing levels of mRNA for transin/stromelysin in both hepatocytes (maximum 24 hours) and lobular mesenchymal cells (maximum 48 hours) after carbon tetrachloride injury (34).

In serum of patients with chronic liver diseases some investigators found increased collagenase activity, while others described profound reductions in serum collagenase activity with development of chronic active hepatitis 


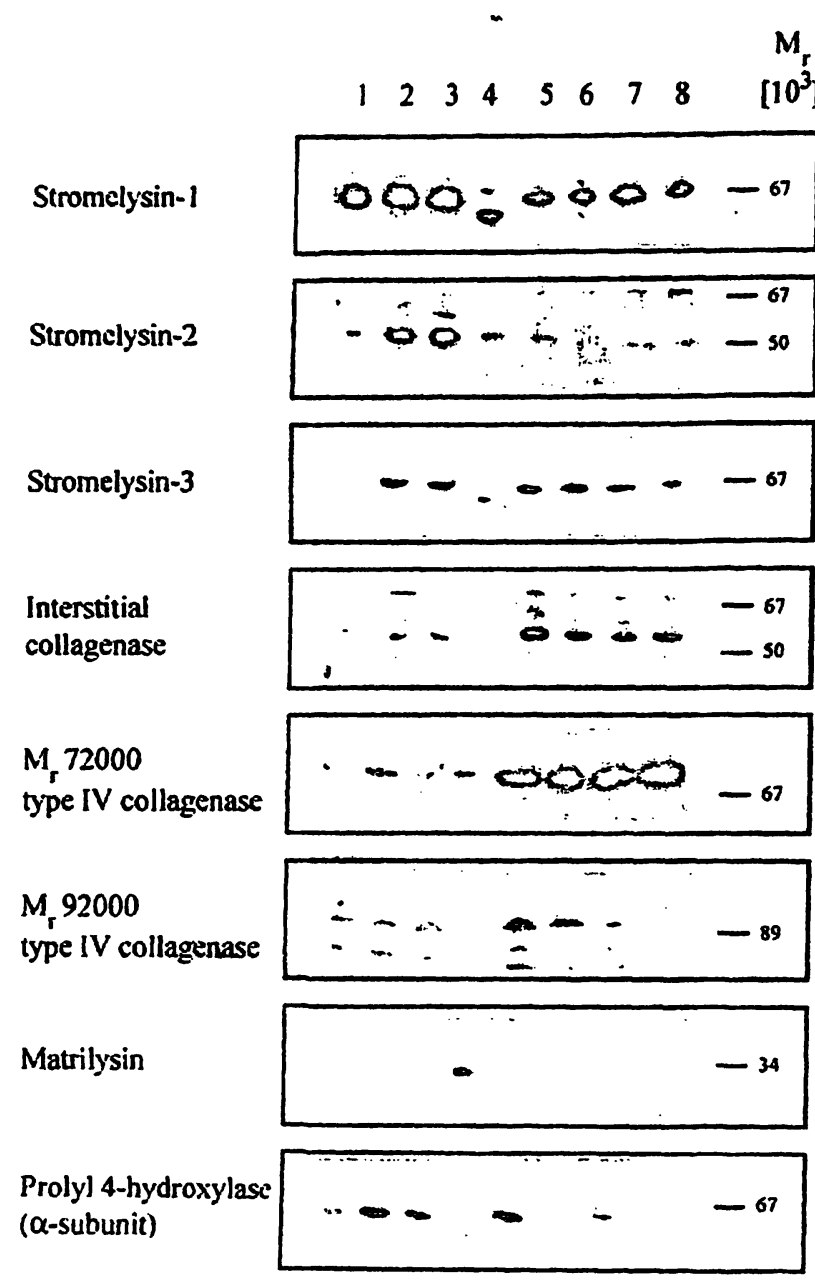

Fig. 3 Expression of different matrix metalloproteinases and prolyl 4-hydroxylase in human liver and liver carcinomas.

Crude tissue preparations (see Materials and Methods) were separately by $9 \%$ SDS polyacrylamide gel electrophoresis and immunoblotted using polyclonal antibodies against stromelysin-1, stromelysin-2, stromelysin-3, matrilysin, $M_{\mathrm{r}} 72000$ type IV collagenase, $M_{\mathrm{r}} 92000$ type IV collagenase, interstitial collagenase and prolyl 4-hydroxylase (antibody dilutions see legend to fig. 2). Tissue preparations were from

hepatocellular carcinoma $(1-3)$;

cholangiocellular carcinoma (4) and

normal human liver $(5-8)$.

Immunoreactive bands were visualized using a luminol-based detection system. No bands of significance were observed in other regions of the gels. For molecular mass markers see legend to figure 2.

(minus 50\% compared with healthy subjects) and cirrhosis (minus 66\%!) (35).

Thus the picture is far from clear. The aim of our own study was, therefore, to describe the pattern of expression of metalloproteinases in normal human liver. Hepatic tumours were used for comparison, since we expected to find higher expression of matrix metalloproteinases in malignant than in normal liver cells.

Our results are surprising in that they show a much more abundant presence of matrix metalloproteinases in normal liver than hitherto described.
Using antibodies against recombinant proteins we were able to show that stromelysin-1 and -3 , interstitial collagenase, and both type IV collagenases $\left(M_{\mathrm{r}} 72000\right.$ and $M_{\mathrm{r}} 92000$ ) are present in healthy human liver. We also detected weak signals for stromelysin- 2 in three of the normal livers analysed. Only matrilysin was not detectable. Interestingly, with regard to the equilibrium hypothesis, we also found varying degrees of prolyl 4hydroxylase expression in normal liver tissue, suggesting that indeed some collagen synthesis takes place.

In the hepatocellular carcinomas we saw expression of all the metalloproteinases tested for, except matrilysin. Stromelysin-2 was also strongly positive in two of the three hepatocellular carcinomas.

$M_{\mathrm{r}} 72000$ type IV collagenase seemed to be less strongly expressed in hepatocellular carcinoma than in normal liver. This may be in accordance with the finding by Murawaki (35) who described reduced levels of collagenase activity in the serum of patients with hepatocellular carcinoma. In the only cholangiocellular carcinoma analysed, there was a completely different pattern of metalloproteinase expression. It was the only tissue in which we were able to detect matrilysin, and it apparently synthesized different forms of stromelysin- 1 and stromelysin-3 from those in normal liver and the hepatocellular carcinomas. This seems entirely possible, since different secreted proenzyme forms of stromelysin have been described in other tissue $(14,36-38)$. Since matrix metalloproteinases are present in tissues mainly in their inactive pro-enzyme form, it is not surprising that our antibodies mainly recognize bands of the molecular mass of these proenzymes. In some of the gels more than one band was identified, suggesting that the antibodies in our polyclonal antisera may recognize other forms of the enzymes as well, such as pre-pro-enzymes, degradation products with partly conserved structure or even enzyme/inhibitor complexes. On the other hand, bands of the size of the active forms were hardly detected, suggesting that the concentration of active enzyme in the tissue is very low. Apparently there is a certain redundancy in the expression of matrix metalloproteinases in the liver, in that almost the whole family of these enzymes can be detected. The precise regulation and cellular origin of these enzymes awaits further study.

\section{Acknowledgement}

This work was supported by a generous grant from the "Gesellschaft der Freunde der MHH". We are greatly endebted to Bernadette Luęns, Sigrid Ohlendorf and Frank Dsiosa for their skilled technical assistance. Thanks are also due to Dr. Augustinus Bader for the generous donation of the tissue samples from explanted normal livers, which were meant for transplantation but could not be utilized for reasons unrelated to this study. 


\section{References}

1. Schuppan D. Structure of the extracellular matrix in normal and fibrotic liver. Semin Liver Dis 1990; 10:1-10.

2. Gressner AM. Liver fibrosis: perspectives in pathobiochemical research and clinical outlook. Eur J Clin Chem Clin Biochem $1991 ; 29: 293-311$.

3. Friedman SL. Cellular sources of collagen and regulation of collagen production in liver. Semin Liver Dis 1990; 10:20-9.

4. Lieber CS. Alcohol and fibrogenesis. Alcohol Alcohol 1991; Suppl 1:339-44.

5. Emonard H, Grimaud JA. Matrix metalloproteinases. A review. Cell Mol Biol 1990; 36:131-53.

6. Arthur MJP. Matrix degradation in the liver. Semin Liver Dis 1990; 10:47-55.

7. Murphy G, Ward R, Gavrilovic J, Atkinson S. Physiological mechanism for metalloproteinase activation. Matrix 1992; Suppl 1:224-30.

8. Milani S, Herbst H, Schuppan D, Hahn EG, Stein H. In situ hybridisation for procollagen types I, III, and IV mRNA in normal and fibrotic human liver. Hepatology 1989; 10:84-92.

9. Arthur MJP, Friedman SL, Roll FJ, Bissell DM. Lipocytes from normal rat liver release a neutral metalloproteinase that degrades basement membrane (type IV) collagen. J Clin Invest 1989; 84:1076-85.

10. Arthur MJ, Stanley A, Iredale JP, Rafferty JA, Hembry RM, Friedman SL. Secretion of $72 \mathrm{kDa}$ type IV collagenase/gelatinase by cultured human lipocytes. Analysis of gene expression, protein synthesis and protease activity. Biochem J 1992; 287:701-7.

11. Maruyama K, Feinman L, Fainsilber Z, Nakano V, Okazaki I, Lieber CS. Mammalian collagenase increases in early alcoholic liver disease and decreases with cirrhosis. Life Sci 1982; 30:1379-84.

12. Linblad WJ, Fuller GC. Hepatic collagenase activity during carbon tetrachloride induced fibrosis. Fundam Appl Toxicol 1983; 3:34-40.

13. Milani S, Herbst H, Schuppan D, Grappone C, Pcllegrini G, Pinzani $M$ et al. Differential expression of matrix metalloproteinase-1 and -2 genes in normal and fibrotic human liver. Am J Pathol 1994; 144:528-37.

14. Arthur MJP. The role of matrix degradation in liver fibrosis. In: Gressner AM, Ramadori, G, editors. Molecular and cell biology of liver fibrogenesis. Dordrecht, Boston, London: Kluwer Academic Publishers, 1992:213-27.

15. Woessner FJ. Matrix metalloproteinases and their inhibitors in connective tissue remodeling. FASEB J 1991; 5:2145-54.

16. Smith DB, Johnson KS. Single step purification of polypeptides expressed in Escherichia coli as fusions with glutathione S-transferase. Gene 1988; 67:31-40.

17. Studier FW, Rosenberg AH, Dunn JJ, Dubendorff JW. Use of T7 RNA polymerase to direct expression of cloned genes. Meth Enzymol 1990; 185:60-89.

18. Ruether U, Mueller-Hill B. Easy identification of cDNA clones. EMBO J 1983; 2:1791-4.

19. Saiki RK, Gelfand DH, Stoffel S, Scharf SJ, Higuchi R, Horn GT. Primer-directed enzymatic amplification of DNA with a thermostable DNA polymerase. Science $1988 ; 239: 487-91$.

20. Whitham SE, Murphy G, Angel P, Rahmdorf HJ, Smith B, Lyons $\mathrm{A}$ et al. Comparison of human stromelysin and collagenase by cloning and sequence analysis. Biochem J 1986; 240:913-6.

21. Muller D, Quantin B, Gesnel MC, Millon-Collard R, Abecassis $\mathrm{J}$, Breathnach $\mathrm{R}$. The collagenase gene family consists of at least four members. Biochem J 1988; 253:187-92.

22. Basset P, Bellocy JP, Wolf C, Stoll I, Hutin P, Limacher JM et al. A novel metalloproteinase gene specifically expressed in stromal cells of breast carcinomas. Nature 1990; 348:699704.
23. Quantin B, Murphy G, Breathnach R. Pump-1 cDNA codes for a protein with characteristics similar to those of classical collagenase family members. Biochemistry 1989; 28:532734.

24. Goldberg GI, Wilhelm SM, Kronberger A, Bauer EA, Grant GA, Eisen AZ. Human fibroblast collagenase: complete primary structure and homology to an oncogene transformationinduced rat protein. J Biol Chem 1986; 261:6600-5.

25. Collier IE, Wilhelm SM, Eisen AZ, Marmer BL, Grant GA, Seltzer JC et al. H-ras oncogene-transformed human bronchial epithelial cells (TBE-1) secrete a single metalloprotease capable of degrading basement membrane collagen. J Biol Chem 1988; 263:6579-87.

26. Wilhelm SM, Collier IE, Marmer BL, Eisen AZ, Grant GA, Goldberg GI. SV40 transformed human lung fibroblasts secrete a $92 \mathrm{kDA}$ type IV collagenase which is identical to that secreted by normal human macrophages. J Biol Chem 1989; 264:17213-21.

27. Helaakoski T, Vuori K, Myllyliä R, Kivirikko KI, Pihlajaniemi $\mathrm{T}$. Molecular cloning of the $\alpha$-subunit of human prolyl 4-hydroxylase: the completc cDNA-derived amino acid sequence for alternative splicing of RNA transcripts. Proc Natl Acad Sci USA $1989 ; 86: 4392-96$.

28. Sanger F, Nicklen S, Coulson AR. DNA sequencing with chain terminating inhibitors. Proc Natl Acad Sci USA 1977; 74:5463-7.

29. Bradford MM. A rapid and sensitive method for the quantitation of microgram quantities of protein utilizing the principle of protein-dye binding. Anal Biochem 1976; 72:248-54.

30. Harlow E, Lane D. Antibodies: a laboratory manual. Cold Spring Harbor Laboratory Press, Cold Spring Harbor, New York, 1988.

31. Seglen PO. Preparation of isolated rat liver cells. Methods Cell Biol 1976; 13:29-83.

32. Hartroff WS, Ridout JH. Pathogenesis of the cirrhosis produced by choline deficiency. Am J Pathol 1951; 27:951-89.

33. Friedman SL, Rockey DC, McGuire RF, Maher JJ, Boyles JK, Yamasaki G. Isolated hepatic lipocytes and Kupffer cells from normal human liver: morphological and functional characteristics in primary culture. Hepatology $1992 ; 15: 234-43$.

34. Herbst H, Heinrichs O, Schuppan D, Milani S, Stein H. Temporal and spatial pattern of Transin/Stromelysin RNA expression following toxic injury in rat liver. Virchows Arch B Cell Pathol 1991; 60:295-300.

35. Murawaki Y, Koda M, Yamada S, Kawasaki H, Shima H, Burkhardt $H$. Serum collagenase activity in patients with chronic liver disease. J Hepatol 1993; 18:328-34.

36. Murphy G, Segain JP, O'Shea M, Cockett M, Ioannou C, Lefebvre $\mathrm{O}$ et al. The $28 \mathrm{kDa}$ N-terminal domain of mouse stromelysin-3 has the general properties of a weak metalloproteinase. J Biol Chem 1993; 268:15435-41.

37. Presky DH, Wilkinson VL, Flannery MD, Korkmaz E. Wasky $\mathrm{R}$, Mondini-Minetti $\mathrm{LJ}$ et al. Production of monoclonal antibodies to prostromelysin and establishment of a quantitative prostromelysin ELISA assay. Biochem Biophys Res Com 1993; 193:364-70.

38. Allan JA, Hembry RM, Angal S, Reynolds JJ, Murphy G. Binding of latent and high $\mathrm{Mr}$ active forms of stromelysin to collagen is mediated by the C-terminal domain. J Cell Sci 1991; 99:789-95.

Dr. Ralf Lichtinghagen

Medizinische Hochschule Hannover

Institut für Klinische Chemie I

Konstanty-Gutschow-Straße 8

D-30625 Hannover

Germany 
$\therefore$ 